\title{
Die geesteswetenskaplike uit die oogpunt van die natuurwetenskaplike
}

Ons beskou wetenskap as die verkryging van kennis op 'n bepaalde terrein en die sistematisering van sodanige kennis, wat op sy beurt lei na verklarings en voorspellings.

Die grens tussen die natuur- en geesteswetenskap is vaag en dikwels onseker, indien nie kunsmatig nie. Tradisioneel is die term natuurwetenskap gereserveer vir die studie van getal, energie, materiële en biologiese sisteme, insluitende die mens insoverre dit sy anatomiese en fisiologiese komponente betref. Menslike aktiwiteite wat denke, emosies en wil insluit, word dan oorgelaat aan die geesteswetenskaplike. Vanselfsprekend sal 'n oorbruggingsgebied soos die sielkunde albei soorte wetenskappe inkorporeer.

Die vaagheid van die grense tussen natuur- en geesteswetenskap neem toe as geredelik aanvaar word dat 'n natuurwetenskaplike studieveld soos bv. die kosmologie, wat 'n blik op die grootheid en grootsheid van die heelal gee, 'n geweldige invloed op die geestelike sy van 'n mens kan uitoefen. Skrywer se Godsbegrip het dimensies hierdeur bygekry wat moeilik uit die teologie gehaal sou kon word en hy is seersekerlik nie die enigste met hierdie ervaring nie; dit het ten minste reeds by Job begin.

Die woorde natuurwetenskaplike en geesteswetenskaplike kan dus hoogstens as operasionele terme beskou word en met só 'n uitgangspunt sal die gegewe onderwerp benader word.

Eerstens dan kritiek en daarna erkenning.

Geesteswetenskaplikes weet en verstaan te min van die natuurwetenskap. Hulle redeneer dat die natuurwetenskaplike studieveld té moeilik en gespesialiseerd is en daarom is insig en kennis nie geredelik bekombaar nie. Terselfdertyd bely hulle ' $n$ groot bewondering vir die natuurwetenskap. Eintlik is dit 'n bewondering vir die tegnologie, wat slegs die toepassing van natuurwetenskap behels. ' $n$ Televisiestel word as 'n wonderlike slim ding beskou, maar die elektromagnetiese golf wat die oudio- en visuele inligting deur die ruimte dra, is nagenoeg irrelevant. Gevolglik is daar min eerlike waardering vir die inherente kultuurwaarde van die natuurwetenskap. Die maatlose presiesheid van al die faktore wat 'n rol moes speel in die totstandkoming van die fisiese heelal, die boekdele genetiese inligting wat bevat word in 'n DNS-molekuul en die kleinheid van die planeet Aarde in die totale hemele kan veel bydra tot die beskeidenheid van sommige politici en tot nuwe temas vir skeppende kunstenaars. Loeloeraai behoort oor en oor vermenigvuldig te word. 'n Fisikus en chemikus weet gewoonweg min van die gedragswetenskappe af. Hy kan wel insien dat dit eintlik enorm kompleks is. Daar is 'n groot aantal veranderlikes en parameters op die spel wat ' $n$ rol speel in die oplossing van bv. 'n sosiopolitiese vraagstuk. Vanuit sy wisk undige agtergrond sal die natuurwetenskaplike besef dat hoe meer parameters ' $n$ algebraïese vergelyking bevat, hoe moeiliker is dit om 'n betroubare oplossing te vind. Dit kan vergemaklik word deur'n aantal parameters gelyk aan nul te maak, met ander woorde: hulle te ignoreer, maar dan is die oplossing nie noodwendig betroubaar nie.

Nou lyk dit al te dikwels of die gedragswetenskaplike, wat 'n gebrek aan wiskundige agtergrond het, te maklik vir sy vraagstukke met enkelparameterantwoorde vorendag kom. Vandaar dat groeperings gekarakteriseer is deur -ismes; om nie eers te praat van die wysbegeerte se menigvuldige strominge nie.

En nou die erkenning en dikwels bewondering vir die geesteswetenskaplike.

Die positiewe bydraes van die geesteswetenskappe tot die geestesgesondheid van die twintigste-eeuse mens is onbetwisbaar. Dit is ' $n$ mooi belewenis om waar te neem hoedat ' $n$ kliniese sielkundige se insig en raad tot die herstel van 'n huwelik, die afleer van 'n swak gewoonte, ens., lei.

As beelddraer van God (al is die beeld soms erg verinneweer) het die mens tog 'n ingebore behoefte daaraan om skoonheid te ervaar. Ook soos dit van die letterkundige of beeldende kunstenaar afkomstig is. 'n Tuin wat net met netjiese, gerieflike bankies en goedbeplande muurtjies en paadjies uitgelê is, maar sonder blomme en struike, sal skaars die moeite werd wees om te besoek. Die funksionele sonder die mooie is dood.

Maar die geesteswetenskaplike se invloed en verantwoordelikheid strek veel verder. Op die lang duur het die spreekwoordelike pen groter effek op die geskiedenis as die ploeg of die swaard. Dink maar aan die invloed wat die verkondigers van die eksistensialisme op die Weste gehad het en nog steeds het. Persone soos Heidegger, Jaspers, Sartre en hulle geesgenote was nie maar net skrywers van abstrakte filosofiese en moeilik verstaanbare letterkundige werke nie. Geleidelik het hulle denkrigtings 'n klimaat in Europa geskep wat gelei het tot ' $n$ gereedheid om bv. die studente-onluste van die sestigerjare te akkommodeer. Sisteem en tegnologie was vyande van die mens en sy reg tot ongebondenheid. Sartre se beswaar teen etiese norme wat van buite af op die mens geponeer word, soos bv. die 
eise van die openbaringsgodsdiens, het tog sekerlik die teelaarde kon help voorberei vir die vinnige opkoms van die situasie-etiek oor die afgelope aantal dekades. As die lewe dan soos' $n$ reis op 'n skip is in 'n donker nag met geen bakens of koersaanwysers nie, dan is die hier en nou binne-in die skip tog immers al wat van belang is. In die proses word die skuldprobleem ook sommer opgelos. As 'n mens dan sy eie etiese gedragsnorme kan bepaal in samehang met sy persoonlike situasie, dan sal hy/sy vanselfsprekend die standaarde laer stel as eie gedrag en sodoende nooit hoef te oortree en skuldig te voel nie!
Die opkoms van die Sestigers in die Afrikaanse letterkunde het groter invloed (soms negatief volgens skrywer se eie lewensbeskouing) op die waardes en gedragsnorme van die Afrikaanssprekende mense van hierdie land gehad as enige ander enkele faktor.

Wetenskaplikes is belaai met wonderlike voorregte en groot verantwoordelikhede, maar die geesteswetenskaplike se invloed is oorheersend. Uiteindelik sal sy/ haar werk ook bepaal wat die mens ook met die natuurwetenskap se produkte, nl. die tegnologie, aanvang.

L. Alberts 